\section{A Framework for Cooperation Across the U.S./Mexico Border}

Philip Heilman, Alicia Melgoza Castillo, Roy Mann, Antonio Chavez Silva, Mark Weltz, Jeffry Stone, Scott Miller, Steve Barker and Dale Fox.

$\mathrm{T}$ The United States and Mexico share many rangeland resources. In the United States terms such as "Sonoran" and "Chihuahuan" are used to describe ecological units that are characteristic of large areas in Mexico. Unfortunately, the development of institutions with different objectives on both sides of the border has led to similar, but somewhat incompatible approaches to documenting the information needed to improve rangeland management. If a common framework could be defined to facilitate the transfer of technology and research across the border, both countries would benefit.

The development of such a framework for rangelands requires agreement on common resource problem definitions, management practice standards, mapping areas of common resources, and developing a common database of management effects on resources. In the United States, technology to support conservation planning has been developed. This could serve as the basis for cooperative research and technology transfer. However, Mexico would need to adapt this technology to its own conditions before implementation. Our paper discusses a number of issues related to sharing range management information. If a framework for cooperation on range research and technology transfer could be developed, the government of Mexico would be in a better position to provide management information to ranchers as recommended recently by Molinar et al. (1998) and there would be benefits to the United States as well.

\section{Status of Conservation Planning in the U.S. and Mexico}

In the United States, the Natural Resources Conservation Service and other institutions have developed technology to support technical assistance for land users. Major components of this conservation planning technology include a planning method, a hierarchical land classification system, natural resource databases, resource problem definitions, and management practice standards. The Bureau of Land Management and the Forest Service also have long term experience managing rangeland resources, but with less emphasis on technology transfer. Research needs in the action agencies are either met in-house, by universities, through Cooperative Extension or the Agricultural Research Service. All of these institutions are facing increasing budgetary pressure and will find it difficult to maintain the same number of researchers and conservationists in the future.

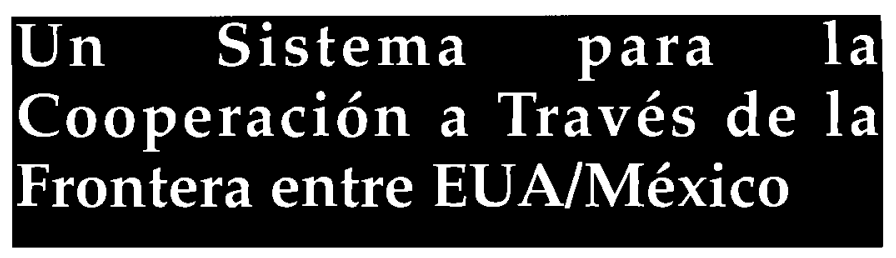

E stados Unidos y México comparten muchos recursos de agostaderos. En Estados Unidos se utilizan los términos como "Sonorense" y "Chihuahuense" que describen unidades ecológicas que son características de grandes áreas en México. Desafortunadamente, en ambos lados de la frontera se han establecido instituciones con diferentes objetivos que han dado como resultado similares, pero hasta cierto punto incompatibles, enfoques como para documentar la información necesaria para mejorar el manejo de agostaderos. El tener un marco de referencia común sería un gran beneficio para ambos países ya que facilitaría programas de investigación y transferencia de tecnología.

El desarrollo de este marco de referencia para agostaderos requiere la definición de los problemas de los recursos en común, normas de prácticas de manejo, mapeo de las áreas con recursos en común y el desarrollo de bases de datos documentando los efectos del manejo de los recursos. En Estados Unidos se ha desarrollado tecnología para apoyar los planes de conservación. Esto puede servir de base para un programa cooperativo sobre investigación y transferencia de tecnología. Sin embargo, México puede adaptar esta tecnología a sus propias condiciones antes de llevar a cabo una implementación. Este trabajo discute algunos temas relacionados con el hecho de compartir información en el manejo de agostaderos. Si se pudiera tener este marco de referencia para un programa cooperativo de investigación y transferencia de tecnología, el gobierno de México podría estar en mejor posición para proporcionar información sobre manejo de agostaderos como lo ha recomendado recientemente Molinar et al. (1998) y esto representaría tambien beneficios para Estados Unidos.

\section{Planeación de la conservación en EUA y México}

En los Estados Unidos, el Servicio de Conservación de Recursos Naturales (NRCS) y otras instituciones han desarrollado tecnologías para apoyar la asistencia técnica para el uso de tierras. Los componentes principales de estas tecnologías incluyen una metodología de planeación, un sistema de clasificación jerárquica de las áreas, base de datos sobre recursos naturales, definición de problemas de recursos y manejo de prácticas estándares. La agencia de gobierno de Manejo de Tierras (BLM) y el Servicio Forestal tienen también una amplia experiencia en el manejo de los recursos naturales, pero con menor énfasis en la transferencia de tecnología. Las necesidades de investigación son cubiertas por el BLM, por el Servicio Forestal, por las universidades, por el Servicio Cooperativo o por el Servicio de Investigación Agrícola (ARS). Todas estas instituciones se están enfrentando a presiones presupuestales, lo que dificultará el mantenimiento de un mismo número de investigadores y conservacionistas en el futuro. 
Mexico does not currently have an institution or national program with the clear responsibility of providing technical assistance comparable to that provided by the Natural Resources Conservation Service. At one time, a program called Centros de Apoyo al Desarrollo Rural Integral (Integrated Rural Development Support Centers) provided technically trained personnel at the local level and collected statistics. The program was dismantled during budget cuts in the mid-1980s. Several Mexican institutions currently support conservation planning on a limited scale, notably the national agricultural research institute, Instituto Nacional de Investigaciones Forestales, Agricolas y Pecuarias and the agency in charge of financing the adoption of improved technology and conservation measures, Fideicomiso de Riesgo Compartido. Although the main purpose of the Instituto Nacional de Investigaciones Forestales, Agrícolas y

Pecuarias is research, it is trying to support technical assistance by training advisors who will work with a group of ranchers called a Grupo Ganadero de Validación y Transferencia de Tecnología. The Fideicomiso de Riesgo Compartido encourages conservation planning through the Alianza para el Campo program by paying up to half the cost for consultants to write a production and conservation plan and is also actively promoting the concept of planning nationwide. Cattlemen's associations in each state also provide some technical assistance.

Historically, there has been cooperation between the U.S. and Mexico on many agricultural issues including research and technology transfer. The Society for Range Management has played a major role, as have a number of universities, cattlemen's associations and consultants. Although past efforts have resulted in a Technical Guide used in southern Mexico (Instituto Mexicano de Tecnología del Agua 1991) and there are local cooperative efforts, currently there is no official large-scale effort to share range management knowledge.

An appropriate role for agencies of both the United States and Mexican governments is to provide a framework that will facilitate the sharing of information about range management. To transparently share information about range management across the border, it is necessary to have common definitions for both management practices and the resource problems they address. National resource problem definitions and management practice standards have been developed by the Natural Resources Conservation Service (described in Sections IV and V of the Field Office Technical Guide). Resource problems are defined in relation to the soil, water, air, plant, animal and human categories, which are used in the conservation planning process.

\section{The Need for a Common Land Classification Scheme}

The basic rangeland management unit recognized on both sides of the border is the "site," an area composed of relatively homogeneous soils, vegetation, climate and topography.

"Range" sites have been described in the United States since 1949 , and the descriptions and interpretations have been continually refined. The recent change in nomenclature from "range" to "ecological" sites is intended to emphasize that the
México actualmente no cuenta con una institución o programa nacional con una responsabilidad específica para proporcionar asistencia técnica comparable al NRCS. En un tiempo, el programa Centros de Apoyo al Desarrollo Rural Integral proporcionaba personal técnico entrenado a nivel local y colecta de datos. Sin embargo, el programa desapareció a mediados de los 80's. Actualmente, algunas instituciones mexicanas apoyan planes de conservación a pequeña escala como el Instituto Nacional de Investigaciones Agrícolas, Forestales y Pecuarias (INIFAP) cuya principal función es la investigación y el Fideicomiso de Riesgo Compartido (FIRCO) cuyo objetivo es el financiamiento en la adopción de tecnología y medidas de conservación. A pesar de que la función de INIFAP es la investigación, actualmente está tratando de apoyar con asistencia técnica al personal, para trabajar con grupos ganaderos en los Grupos Ganaderos de Validación y Transferencia de Tecnología (GGAVAT). El FIRCO promueve planes de conservación a través del programa Alianza para el Campo, al pagar la mitad del costo a los consultores para desarrollar un plan de producción y conservación a nivel regional y nacional. También, las Asociaciones Ganaderas en cada estado proveen asistencia técnica.

Históricamente, ha existido cooperación entre EUA y México en diversos temas de agricultura incluyendo investigación y transferencia de tecnología. La Sociedad de Manejo de Pastizales (SRM) ha jugado un papel muy importante al incluir en ésta, a universidades, asociaciones ganaderas y consultores. A pesar de que en el pasado se han hecho trabajos que han dado como resultado una Guía Técnica usada en el sur de México (Instituto Mexicano del Agua, IMTA, 1991) y de que existen esfuerzos de cooperativas locales, actualmente no existe oficialmente un plan de acción a nivel nacional para compartir el conocimiento sobre manejo de agostaderos.

Tanto las agencias de EUA como las de México podrían proporcionar un marco de referencia común que facilitara la información en el manejo de agostaderos. Para tener una claridad al compartir información a través de la frontera es necesario tener definiciones comunes sobre la problemática y las prácticas de manejo de los recursos en juego. La definición de problemas sobre recursos naturales y prácticas de manejo han sido desarrolladas por el NRCS (descritas en las Secciones IV y V de la Guía Oficial de Técnicas de Campo). Los problemas sobre recursos son definidos con relación a suelo, agua, aire, planta, animal y hombre, los cuales son utilizados en el proceso de planeación de conservación.

\section{La necesidad de un esquema de clasificación de tierra común}

La unidad de manejo de pastizales básica reconocida en ambos lados de la frontera es llamada el "sitio", un área homogénea en cuanto a suelo, vegetación, clima y topografía. Los "sitios de agostadero" han sido descritos en EUA desde 1949, y la descripción e interpretación han sido continuamente perfeccionadas. El cambio reciente de "sitios de agostadero" por "sitios ecológicos" enfatiza que los sitios son unidades ecológicas más que productoras de forraje exclusivamente. En EUA, el NRCS es responsable de definir y de- 
concept and description of sites are ecologically, rather than forage-production based. In the United States, the Natural Resources Conservation Service is responsible for defining and describing ecological sites. An ecological site is defined (1997) as "a distinct kind of land with specific physical characteristics that differs from other kinds of land in its ability to produce a distinctive kind and amount of vegetation."

An essential component of the ecological site description is the composition of the potential plant community. Once a part of the landscape has been classified as being in a certain ecological site, existing vegetation can be compared to the site's potential plant community or to other possible seral stages or states, and interpretations can be made about the potentials and limitations for forage production, risk of erosion, wildlife habitat, and other objectives. Ecological sites thus provide a basis for the establishment of realistic management objectives on rangeland.

In Mexico, a similar system is used to define and describe "Sitios de Productividad Forrajera" or Forage Production Sites. These are defined as areas with a topography, soil, plant composition and climate that result in different levels of forage production. The institution responsible for defining and describing these sites is the Comision Technico Consultiva de Coeficientes de Agostadero or "Technical Commission for Stocking Rates." This institution was originally charged with determining stocking rates to support land redistribution efforts, notably to limit ranch size to 500 animal units. In a major effort during the years 1973 to 1978 , Forage Production Sites were defined, described and mapped for all the states in Mexico.

As can be seen in Table 1, the information contained in the site descriptions in both systems is similar. The table also compares information typically contained in the old Natural Resources Conservation Service format to that contained in the new format, as described in the 1997 National Range and Pasture Handbook. The differences between the two countries' approaches to describing sites stem from their different cribir los sitios ecológicos. Un sitio ecológico es definido (1997) como " un tipo distinto de tierra con características específicas físicas que difieren de otros tipos de tierra en su habilidad para producir un tipo y cantidad de vegetación diferente".

Un componente esencial en la descripción de sitio ecológico es la composición del potencial de su comunidad vegetal. Una vez que una parte del paisaje ha sido clasificada en cierto sitio ecológico, la vegetación existente puede ser comparada con la vegetación potencial del sitio $\mathrm{u}$ otro posible estado seral y las interpretaciones pueden ser hechas con base en su potencial y limitaciones en producción de forraje, riego de erosión, hábitat para fauna u otros objetivos. Así, los sitios ecológicos proveen una base para el establecimiento de objetivos múltiples en agostaderos.

En México, un sistema similar ha sido desarrollado para definir y describir los "Sitios de Productividad Forrajera". Éstos son definidos con base en clima, topografía, suelos y plantas lo que da como resultado diferentes niveles de producción de forraje. La institución responsable de esta descripción y definición de sitios es la Comisión Técnico Consultiva de Coeficientes de Agostadero" (COTECOCA). Esta institución surgió con la necesidad de determinar las cargas animales para apoyar en la distribución de tierra y limitar el tamaño de ranchos a 500 unidades animal. En un gran esfuerzo, durante los años 1973 a 1978 los Sitios de Productividad Forrajera fueron definidos, descritos y se elaboraron mapas en todos los estados de México.

La Tabla 1 muestra las similaridades de la información contenida en la descripción de sitios en ambos sistemas. La tabla también incluye la información del anterior formato del NRCS y el nuevo formato descrito en 1997 en el Anuario Nacional de Pastizales y Forrajes. La diferencia de los enfoques en los dos países al describir sitios es debida, principalmente, a la diferencia de los objetivos de las instituciones. Otra gran diferencia es el enfoque ecológico en los Estados Unidos que puede ser interpretado como producción de forraje u otros usos y el de México que es principalmente para

Table 1. Comparison of information typically included in site descriptions

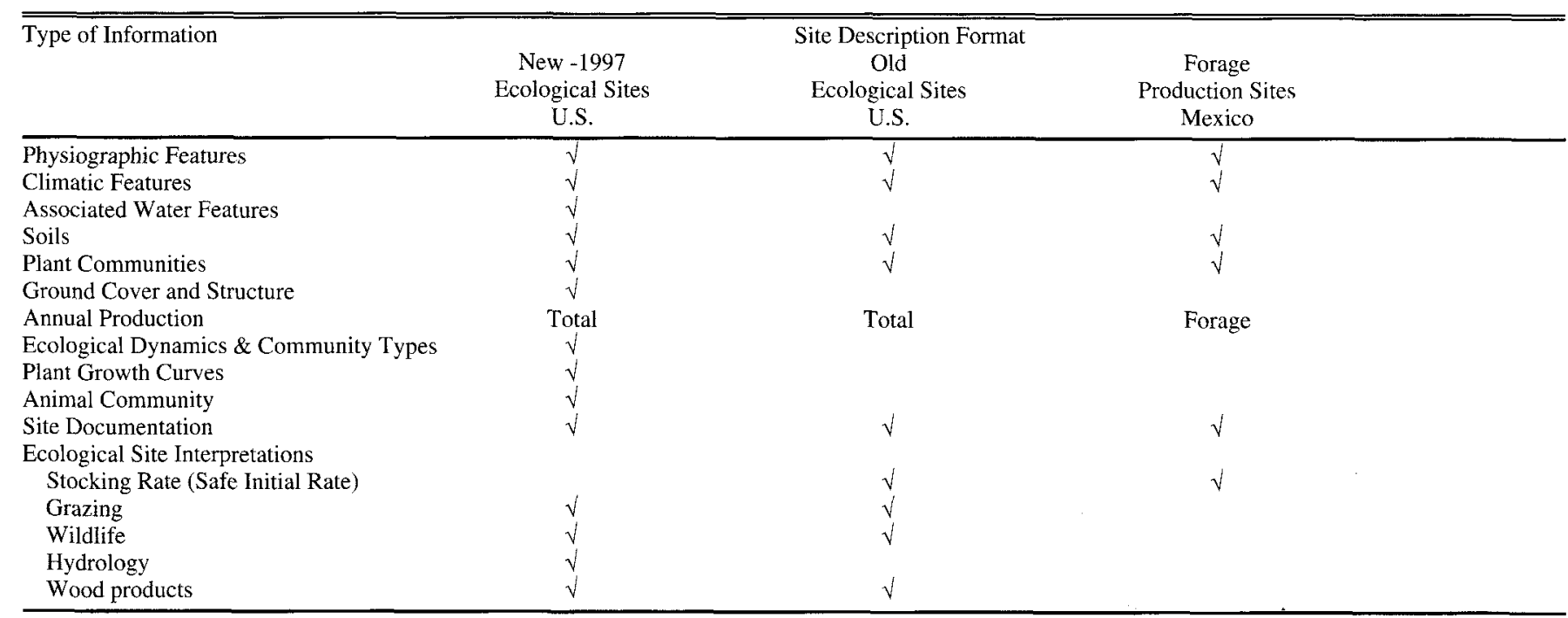


objectives. A major difference is an emphasis on an ecological basis in the United States that could be interpreted for forage production or other uses and the Mexican system that is primarily to estimate forage production. The second major difference is that the ecological site descriptions usually contain additional management information related to other rangeland uses.

Defining sites on an ecological, rather than forage, basis leads to a finer resolution of sites in the U.S. The relative numbers of ecological sites defined in Arizona and forage production sites in Chihuahua provides a rough comparison of the difference in resolution of the two systems. In Arizona, 503 ecological sites are defined over a total area of $29 \mathrm{~m}$ hectares. In Chihuahua, 64 forage production sites are defined for $24 \mathrm{~m}$ hectares. Per unit area then, there are almost 7 times as many ecological sites defined in Arizona as there are forage production sites defined in Chihuahua. Both approaches distinguish areas with the potential for homogeneous stands, such as sacaton bottoms, as separate sites. However, the Natural

Resources Conservation Service defines more sites in areas with heterogeneous plant communities, even though those sites could all have the same forage production capability.

One key to sharing data across the border is to link ecological sites in the U.S. to their corresponding forage production sites in Mexico. As a practical matter, the easiest way to do this would be to take advantage of the hierarchical structure of the land classification scheme developed by the Natural Resources Conservation Service (USDA, 1981), see Figure 1.

If the forage production sites that have already been mapped in Mexico could be linked to the Major Land Resource Areas and Land Resource Units mapped along the U.S. border, then Major Land Resource Areas could be mapped across the border into Mexico. Of course, fieldwork would be required to confirm that the response to management in these areas is similar enough to share information, and to adjust map boundaries. Other existing sources of information would support this estimar la producción de forraje. Otra diferencia es que las descripciones de sitios ecológicos comúnmente contienen información adicional sobre manejo relacionada a otros usos de la tierra.

Al definir los sitios con bases ecológicas, en vez de con base en producción forrajera, da como resultado una más fina resolución de sitios en EUA. El número de sitios ecológicos definidos para Arizona y los sitios de productividad forrajera en Chihuahua dan una idea de la diferencia en la resolución de sitios. En Arizona, 503 sitios ecológicos están descritos en un total de 29 milliones de hectáreas. En Chihuahua, 64 sitios de productividad forrajera están definidos en un total de 24 milliones de hectáreas. Por lo que comparando, por unidad de área, existen más de 7 sitios ecológicos en Arizona por cada sitio de productividad forrajera en Chihuahua. Ambos enfoques distinguen en áreas homogéneas, como los bajíos con zacatón, como sitios diferentes. Sin embargo, el NRCS define más sitios en áreas con comunidades heterogéneas, a pesar de que estos sitios puedan tener igual capacidad en la producción de forraje.

Una clave para compartir información a través de la frontera es comparar y relacionar los sitios ecológicos de EUA a sus correspondientes sitios de productividad forrajera en México. Esto se podría iniciar aprovechando la estructura jerárquica de la clasificación de la tierra desarrollada por el NRCS (USDA, 1981), ver Figura 1.

Si los sitios de productividad forrajera, ya elaborados por COTECOCA en México, pudieran ser asociados con los mapas de Áreas Mayores (MLRA) y sus componentes (LRU) entonces se tendría un área de recursos en común a través de la frontera. Para esto sería necesario el trabajo de campo para corroborar las similaridades y ajustar los límites del mapa en México. Otras fuentes de información podrían apoyar este trabajo. Por ejemplo, la Figura 2 muestra una estimación preliminar de la extensión del MLRA 41, Bolsones y Planicies del Sudoeste de Arizona y la LRU a la que está asociada a través

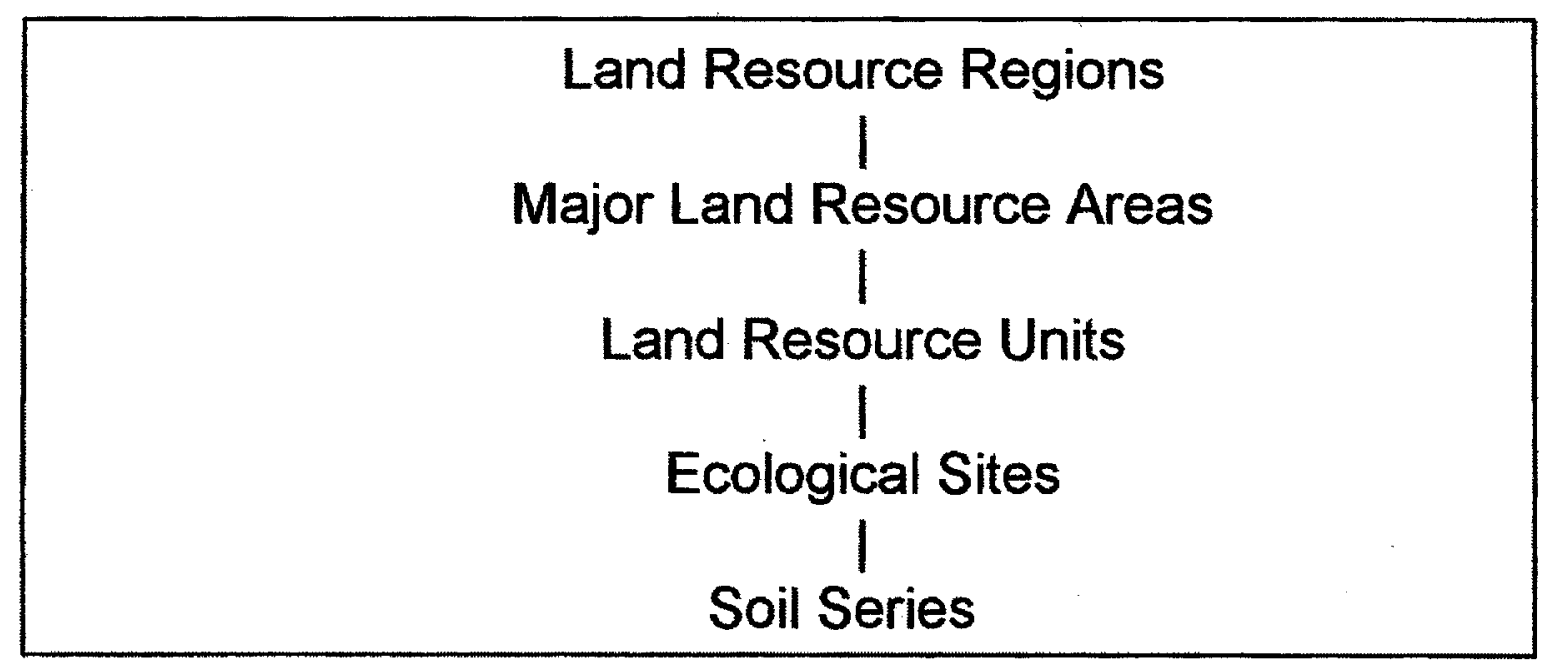

Fig. 1. Natural Resources Conservation Service Hierarchical Classification System 


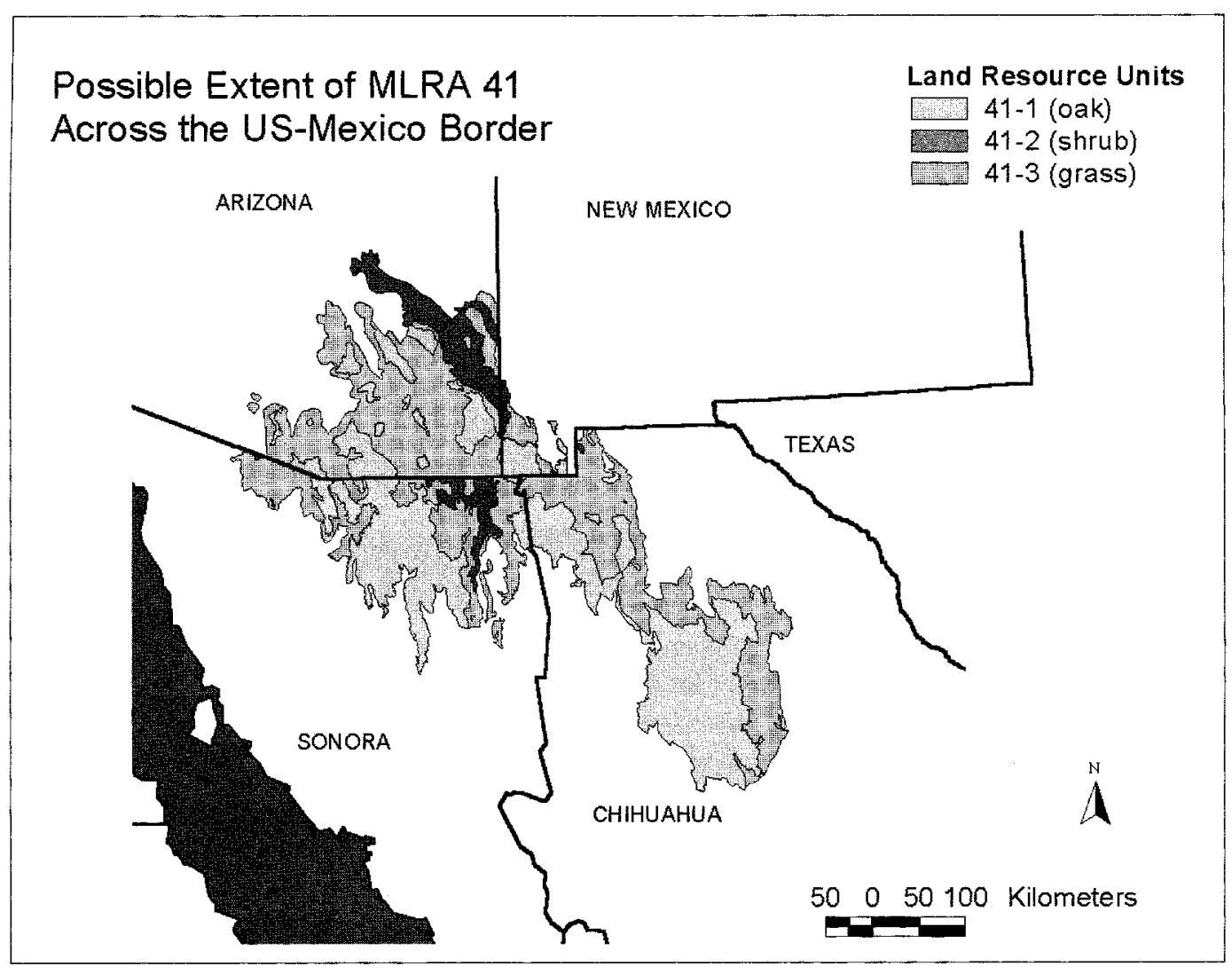

Fig. 2. Preliminary estimate of Major Land Resource Area 41 in both the U.S. and Mexico

effort. For example, Figure 2 shows a preliminary estimate of the extent of Major Land Resource Area 41, Southeastern Arizona Basin and Range, and its associated Land Resource Units, across the border. This preliminary map is based on Brown and Lowe (1994) and several visits.

The lowest level in the Natural Resources Conservation Service hierarchical classification on rangelands is the soil series. Mapping common Major Land Resource Areas across the border would permit correlation of soils as well as ecological sites. Mexico uses the Food and Agriculture Organization soil classification system, which has been correlated to the Suborder and Great Group level of Soil Taxonomy (USDA 1993). There has been significant cooperation across the border on soil science issues in the past, for example, see IMTA (1990).

\section{Conclusion}

A common framework for research and technical assistance to ranchers based on shared natural resources would provide benefits to both the U.S. and Mexico. The framework proposed in this paper, consisting of common resource problem and management system definitions and the delineation of common Major Land Resource Areas across the border, is essentially proposing that some ecological site concepts used in the U.S. be adapted for use in Mexico. Although the ecological site approach is not perfect, it would be difficult to modify, because it has developed over many years and has been institutionalized across a broad spectrum of USDA programs. de la frontera. Este mapa preliminar está basado en Brown y Lowe (1994) y visitas de campo.

En la clasificación del NRCS, el nivel más bajo en la jerarquía es las series de suelo. Por lo que al extender el mapa de las MLRA a través de la frontera permitirá la correlación de suelos así como de sitios ecológicos. México usa el sistema de clasificación de suelos de la Organización de las Naciones Unidas para la Agricultura y la Alimentación (FAO), la cual ha sido correlacionada con la taxonomía de suelos de EUA (USDA, 1993). Este no sería el primer trabajo cooperativo en suelos; el IMTA (1990) es un ejemplo.

\section{Conclusión}

Sería de gran beneficio para ambos países el tener un marco de referencia común entre EUA y México para llevar a cabo investigación y transferencia de tecnología, basándose en información compartida. El marco de referencia propuesto en este trabajo, la definición de problemas de los recursos y sistemas de manejo y la delimitación de MLRA en México, esencialmente propone que algunos conceptos de sitios ecológicos usados en EUA sean adaptados para su uso en México. A pesar de que el enfoque de sitios ecológicos no es perfecto, es difícil de modificar porque ha sido desarrollado desde hace tiempo e institucionalizado en diferentes programas de USDA. Por otra parte, provee el beneficio de documentar el conocimiento ecológico existente. Debido a que en México no existe una sola institución responsable de la transferencia de 
Also, it provides the benefit of documenting existing ecological knowledge. As there is no single institution in Mexico responsible for technology transfer through direct technical assistance, adapting the Natural Resources Conservation Service approach to Mexico would not require abandoning an existing approach. Lastly, given limited resources, it would be much easier to incorporate data from both the U.S. and Mexico into the existing Natural Resources Conservation Service approach for application in both countries than to try to define a new system and get both countries to adopt it.

Potential benefits from a common framework include: a process to more easily define natural resource issues of common interest and concern; identification of common research needs related to soil, water, air, plant, and animal resources; expanded technology development; stronger technology transfer programs linking research through technical assistance to ranchers; and ultimately, more productive and healthier rangelands and rural communities.

The immediate benefit to Mexico would be access to the knowledge contained in ecological site descriptions for the areas adjacent to the U.S./Mexico border. Interpretations for management on matters other than forage production, such as for watershed protection or wildlife habitat, could be based on ecological sites. The primary benefits to the U.S. would be access to additional data and knowledge for common ecological areas and the ability to share the burden of future research and technology development.

As both potential costs and benefits should be considered, it is worth noting that Mexico would experience both higher costs and benefits than the U.S. Mexico would have to adapt conservation planning technology developed in the U.S. to its own conditions and institutions. In addition, the cost of providing expanded conservation planning assistance to Mexican ranchers over large areas would be substantial. The cost to the U.S. of incorporating information from Mexico and cooperating on database design and research programs would be smaller by comparison.

A preliminary evaluation of existing data indicates that many pieces are already in place, and that the potential for correlation of important natural resource information is both feasible and practical. A framework to facilitate sharing range management information consisting of shared resource problem and management practice definitions for areas with similar vegetation and soils along the border would provide economic and ecological benefits to both countries.

\section{References and Additional Resources}

Brown, D.E., and C. H. Lowe. 1994. Biotic Communities of the Southwest, University of Utah Press, Salt Lake City, Ut.

Comisión Tecnico Consultiva para la Determinación Regional del los Coeficientes de Agostadero. 1978. Chihuahua, Secretaria de Agricultura y Recursos Hidraulicos.

Flores, M.G., J. Jimenez, X. Madrigal, F. Moncayo, and F. Takaki. 1971. Memoria del mapa de tipos de vegetacion de la Republica Mexicana. Secretaria de Recursos Hidráulicos. México, D.F.

Instituto Mexicano del Tecnologia del Agua (IMTA). 1991. Guía

Técnica para producción y conservación en el trópico, 1a reimpresión, Secretaria de Agricultura y Recursos Hidráulicos.

Instituto Mexicano del Tecnologia del Agua (IMTA). 1990. tecnología a través de asistencia técnica directa, el adaptar el enfoque del NRCS no representa el abandono de los enfoques existentes. Por último, dado los recursos financieros limitantes, es mucho mas fácil incorporar la información de ambos países al enfoque actual del NRCS para la aplicación en ambos países que el tratar de definir un nuevo sistema y hacer que ambos países lo adopten.

Los beneficios potenciales de un marco de referencia común incluyen: un sistema para más fácilmente definir aspectos sobre recursos naturales de interés común, identificación de necesidades de investigación, extender el desarrollo de tecnología, programas de transferencia de tecnología relacionados con investigación a través de asistencia técnica a ganaderos y agostaderos y comunidades rurales en mejor condición y mas productivos.

El beneficio inmediato para México sería el utilizar la descripción de sitios ecológicos en áreas adyacentes a la frontera. Así se contaría con información sobre calidad de hábitat para fauna, manejo de cuencas, etc. Un beneficio para EUA sería también el acceso a información sobre sitios ecológicos para en un futuro planear investigación y transferencia de tecnología en forma cooperativa.

México tendría mayores costos y beneficios que EUA al adaptar las tecnologías desarrolladas en EUA, ya que debería adaptarlas a sus propias condiciones e instituciones. Pero además, sería substancial el costo al extender la asistencia en la planeación de la conservación en ranchos mexicanos a lo largo de áreas grandes. El costo para EUA al incorporar información de México y cooperar en el diseño de la base de datos y programas de investigación sería menor.

Afortunadamente, una evaluación preliminar de los datos existentes indican que mucho del trabajo ya está hecho y que es muy posible y factible la correlación de información sobre recursos naturales. Un marco de referencia sobre problemas comunes de recursos y definición de prácticas de manejo tendría beneficios ecológicos y económicos para ambos países.

Introducción a la Taxonomia de Suelos, Secretaria de Agricultura y Recursos Hidráulicos.

Molinar, F., H de S. Gomes, J.L. Holechek and R. Valdez. 1998. Mexico, Macro-Economics, and Range Management. Rangelands 20(4) 16-24.

Natural Resources Conservation Service. 1997. National Range and Pasture Handbook, page 3.1-1.

Rzedowski, J. 1978. Vegetación de México. Editorial Limusa, México.

USDA Soil Conservation Service. 1981. Agriculture Handbook 296

Land Resource Regions and Major Land Resource Areas of The United States, Washington, D.C.

USDA Soil Conservation Service. 1993. World Soil Resources, Correlation of Soil Taxonomy with the Legend of the FAO-UNESCO Soil Map of the World.

The authors are with the USDA-ARS Southwest Watershed Research Center, 2000 E. Allen Rd., Tucson, AZ 85719; Rancho Experimental La Campana, Apdo. Postal 1204, Chihuahua, CHIH., Mexico; USDA-NRCS retired; Rancho Experimental La Campana; USDA-ARS Great Plains'Systems Research Unit, P.O. Box E, 301 South Howes Street, Fort Collins, Colo. 80522; Southwest Watershed Research Center; USDA-NRCS, 3003 N. Central Ave., Suite 800, Phoenix, Ariz. 85012-2945; and USDA-NRCS, 2000 E. Allen Rd., Tucson, Ariz. 85719 , respectively.

Acknowledgement: The authors would like to recognize the help of Rafael Fierros Rodriguez, Arturo Bolaños Medina, Don Breckenfeld and Dan Robinette. 